Periodica Polytechnica Civil Engineering, 64(1), pp. 60-64, 2020

\title{
The Effect of the Wood Defects on Fire Resistance
}

\author{
Zsolt Cimer¹, Olivér Czoboly², Béla Harmann², Éva Lublóy²* \\ ${ }^{1}$ National University of Public Service, Faculty of Water Sciences, National University of Public Service, 1083 Budapest, \\ Ludovika tér 2., Hungary \\ 2 Department of Construction Materials and Technologies, Faculty of Civil Engineering, Budapest University of Technology and \\ Economics, H-1521 Budapest, Műegyetem rakpart 3., Hungary \\ *Corresponding author, e-mail: lubloy.eva@epito.bme.hu
}

Received: 18 August 2019, Accepted: 21 November 2019, Published online: 19 December 2019

\begin{abstract}
In the case of charcoal speeds, the defects of the wood and the effect of the metal fixing elements are not taken into account. The aim of our research was to analyze and investigate the effect of wood defects and fasteners on fire resistance. During the experiments we investigated the effect of the defects in the wood and the effect of the metal fasteners on the fire resistance. In the first part of the experiments we examined the effect of wooden defects (knots, thread direction, cracks, insect repellent) on fire resistance. We assumed that the higher hardness or density of the knots and the different fiber direction would facilitate the burning of the wood in the vicinity of the knot. In our experiments, we also examined the effects of cracks and insect pests. The second part of our experiment was to test the switching elements under the effect of heat load.res.
\end{abstract}

\section{Keywords}

wood defect, fire resistance, heat load, impact assessment

\section{Introduction}

The high temperature during the fire impact leads to significant chemical changes in the wood. This is illustrated in Fig. 1. The combustion of wood is manifested in both heat generation and carbonization. During the pyrolysis, flammable gases generate, which may ignite near the wood surface, as long as the glow means surface glow.

The chemical transformation of wood is shown in Table 1, as a function of the temperature [1].

In this paper, the authors investigate the chemical effects of wood. Based on the tests, the depth of the carbonization ( $\mathrm{d}_{\text {char }}$ charring depth) and the thermal decomposition zone can be described in a linear relation:

Fig. 1 shows the thermal decomposition zone in addition to the chemical effects.

Table 1 Chemical transformations of wood as a function of the temperature (made by the authors)

\begin{tabular}{lc}
\hline Temperature & Phenomenon \\
\hline $600-700{ }^{\circ} \mathrm{C}$ & The surface of wood is glowing \\
$330{ }^{\circ} \mathrm{C}$ & Self-ignition of wood \\
$250-300{ }^{\circ} \mathrm{C}$ & Constant combustion of exhaust gases \\
$200-250{ }^{\circ} \mathrm{C}$ & Flashpoint of wood \\
$100-200{ }^{\circ} \mathrm{C}$ & Carbonization of the surface \\
$100{ }^{\circ} \mathrm{C}$ & The leave of moisture content in wood \\
\hline
\end{tabular}

carbonized layer smouldering layer (thermal decomposition zone)

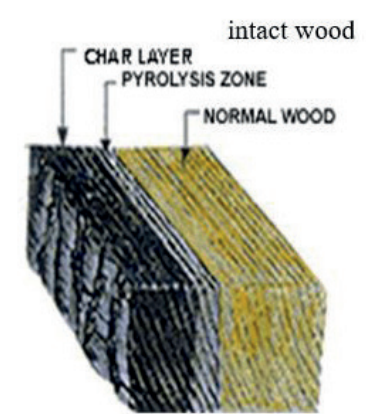

Fig. 1 Layers of wood during the combustion [2]

The charring rate, beyond many other parameters, depends mainly on the species of wood, the density of the wood, and the geometry of the cross-section. We aimed to describe the visible and measurable physical changes in the fire samples. Changes in the fire effect are very diverse. The heat effect creates various marks on wood such as oxidation, carbonation, deposition of smoke and soot, discoloration due to burning, changes in the properties and structure of the test wood and the total consumption of combustible wood [3-5]. 
In case of the charring rate, it does not take into account the defects of the wood or the effect of the metal fasteners. During the tests, we would like to draw attention to the importance of these factors [6-10].

\section{The effect of the wood defects on fire resistance}

The typing and detailing of wood defects are not included in this paper. Only the effect of knots, cracks and insecticides on fire resistance is investigated. In this paper, the authors present the test results and the related research suggestions.

We conducted our tests on specimens with different sizes and shapes, exposing the elements to different heat effects. In case of two tests, the type of wood was the same. The wood was under heat load in an electric furnace and under an open flame.

\subsection{Effect of knots}

In this series of experiments, relatively small $(7 \mathrm{~cm} \times 7 \mathrm{~cm}$ $\times 7 \mathrm{~cm}$ ) specimens were tested. The test was also performed on a standard wood sample, which was free of material defects. In addition, 8 samples with knots of various positions and sizes were examined.

In the first experiment, the specimens were heated in an electric furnace according to the standard fire curve. The elements were heated until ignited spontaneously. It occurred at about $490^{\circ} \mathrm{C}$. Fig. 2 illustrates the heating of the specimens in the electric furnace.

As shown in Fig. 2, no open flame was used to ignite the elements. Then we removed the elements from the furnace, and we allowed it to burn for 2-3 minutes before being placed it in water. The following day, the elements were shown through the knots. The combustion process of wood after the removal of the wood elements from the furnace is shown in Fig. 3.

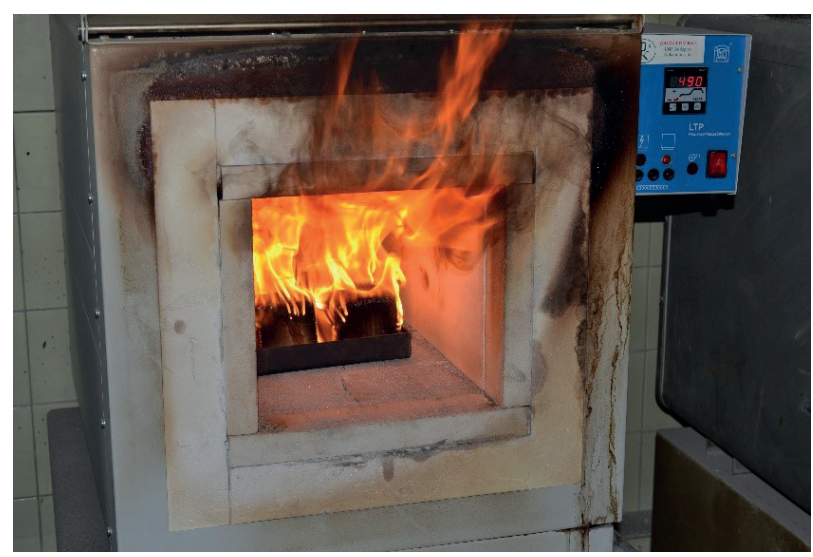

Fig. 2 Burning elements in the furnace (made by authors)

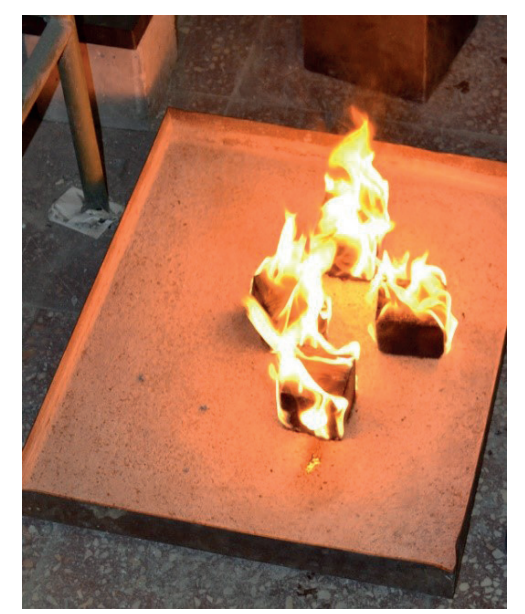

Fig. 3 Burning of specimens in the open air (made by authors)

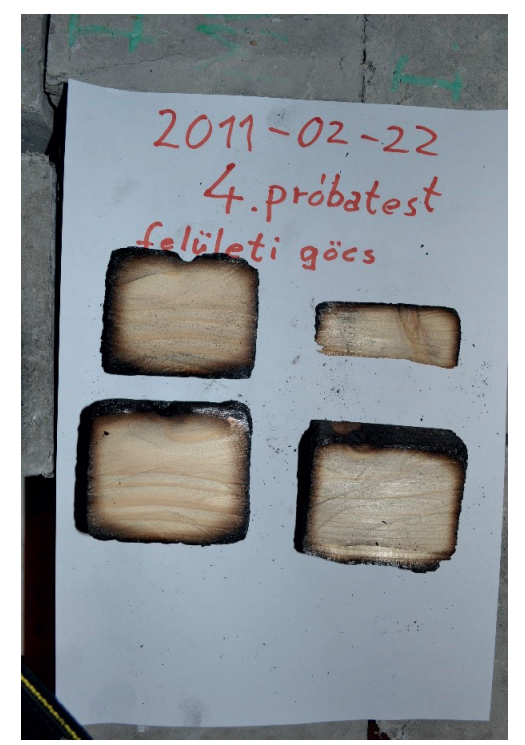

Fig. 4 Varying burn levels in case of different grainlines and perpendicular to it (made by authors)

After sawing, we experienced that the elements were only slightly carbonized. Next to a knot, which is perpendicular to the surface, we could not have observed any significant burns. The specimens showed that the wood burned to varying levels in case of perpendicular grainline and parallel grainline. We can see the varying burn levels in case of different grainlines in Fig. 4.

However, in case of knots parallel to the surface, it is observed that the knot has been dropped out. Thus, the material is damaged deeper than burn the surface. Fig. 5 shows the damages of depth of the knots, which are parallel to grainlines after dropout.

In the second series, the elements were heated to a maximum temperature of $300{ }^{\circ} \mathrm{C}$, as long as the elements start to glow, before the self-ignition. After reaching the temperature of $300^{\circ} \mathrm{C}$, the specimens were heated for 30 minutes. 
As a result of the experiment, no significant changes were observed near the knots. Most of the moisture was evaporated from the specimens. The current specimens were much more comfortable cut through than the specimens we tested in the previous series. (In both series, specimens with same material were tested). In the second series, it can be clearly observed that hardly any carbonized layer was formed on the surface. Therefore, the burn of knots cannot be well studied with these parameters.

In the third series of tests, the specimens were exposed to open flame. Some specimens had only one surface exposed to open flame and some that exposed both sides. In case of the specimens we could not provide the heat load corresponding to the standard fire curve, because we heated the specimens in a grill.

The specimens show us that there is a recess near the knots. This is illustrated in Figs. 6 and 7. The recess indicates that the wood burns faster near the knot. (This phenomenon may contribute to the fact that the knots have a smaller shrinkage than the rest of the wood.)
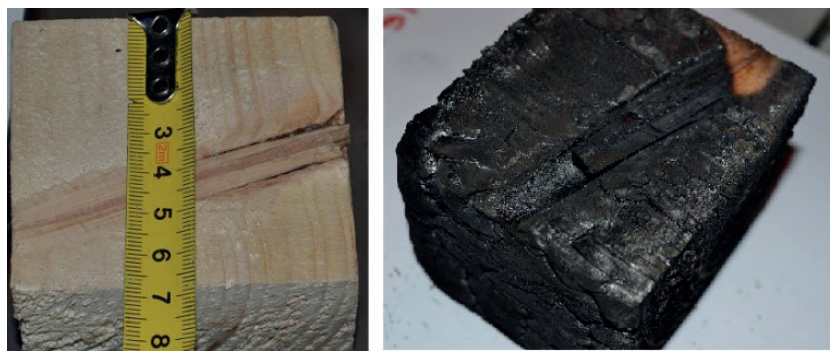

Fig. 5 Drop of the knots that are parallel of the surface (made by authors)

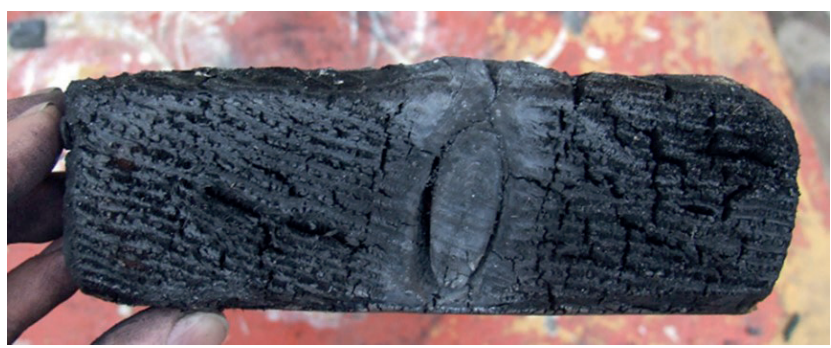

Fig. 6 A so-called "ditch" recess near the knot (made by authors)

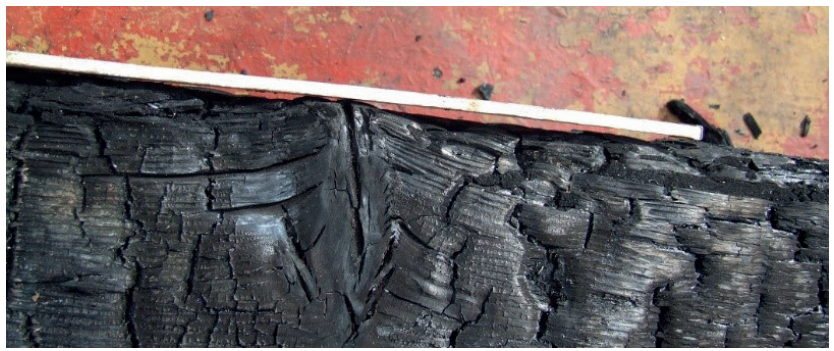

Fig. 7 A so-called "ditch" recess near the knot (made by authors)
We also observed the recess near the knot in the previous series, but it could not be clearly shown there. However, in this series of tests the phenomenon can be observed on several specimens.

\subsection{Effect of insecticides}

On one of the specimens, some traces of insect bites can be seen. When we cut the specimen, we recognized that the insect's route did not burn. So the fire resistance of the wood was not affected by the insect pests. The extent of insect pests on burning is illustrated in Fig. 8.

\subsection{Effect of cracks}

The effect of the cracks was investigated on columnar specimens. Its size was approximately $3 \mathrm{~cm} \times 3 \mathrm{~cm} \times 18 \mathrm{~cm}$. Some longitudinal cracks were observed on the specimens before the start of the test. During the heat load and cooling, the thickness of the crack was increased. It resulted in audible cracks. The elements are greatly deformed. Fig. 9 shows the deformation of the elements.

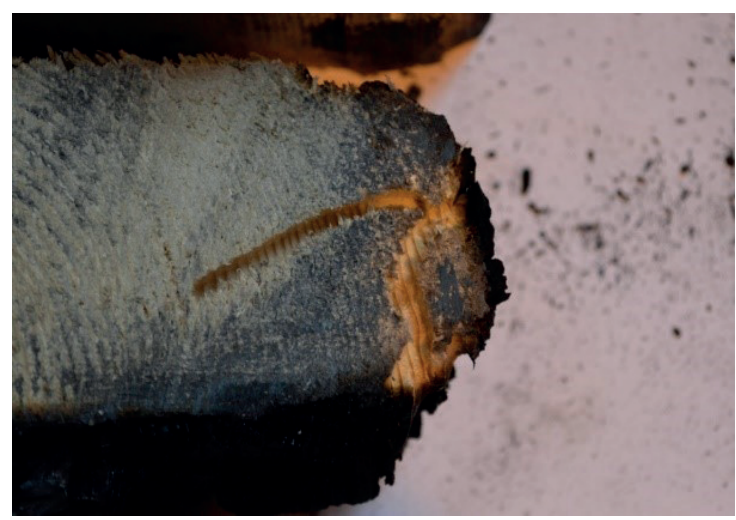

Fig. 8 The level of burn on an insecticide specimen (made by the authors)

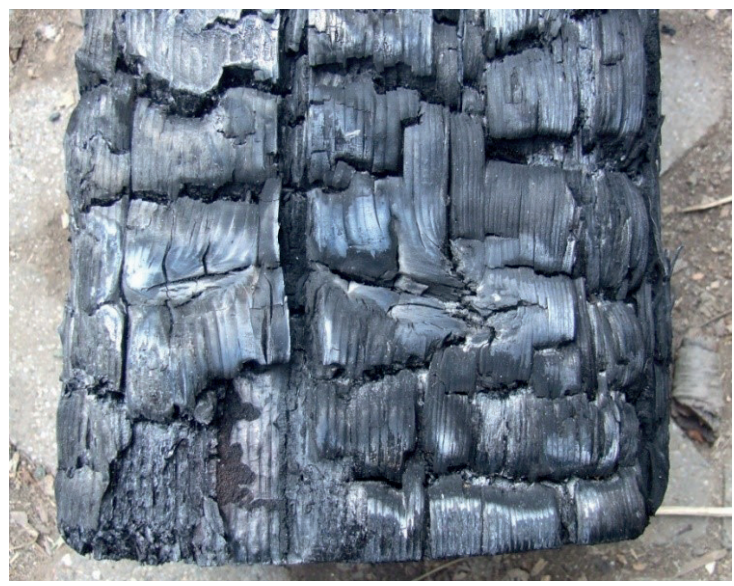

Fig. 9 Cracks on the carbonized surface (made by the authors) 
Then we examined the effect of the open flame on the test specimens. In this case, we left the specimens in the fire for different times (from $6 \mathrm{~min} 30 \mathrm{sec}$ to $10 \mathrm{~min}$ ). Here we already tested larger specimens $(5 \mathrm{~cm} \times 15 \mathrm{~cm}$ size plank pieces). On the surface of the elements a thicker carbonized layer was formed. We could see some visible cracks on the carbonized surface. It can also be seen in Fig. 10. The question is how well the cracked carbon layer can provide thermal insulation to the wood. So, it is questionable to what extent the thermal insulation capacity of the carbonized layer can be taken into account during the calculations.

\section{Effect of the metal elements on the fire resistance}

In this experimental section, the effect of metal switching elements was investigated. We beat an angle in the specimen and investigated the effect of heat load on the metal element. As shown in Fig. 10, the material burned more in the corners of the specimens. This phenomenon has been observed so far during the experiments. It looks as if the angle is contributing to the absence of any visible coloration of the wood in that area.

Here, the authors note that it would be useful to take a test, on larger specimens, whether the angle changed the behavior of the tree, or they can only be explained by the fact that the specimen overheats the corner better. In addition, the effect of the angle against the heat load of an open flame should also be investigated.

In case of screws with a larger diameter a significant carbonization was observed as shown in Fig. 11.

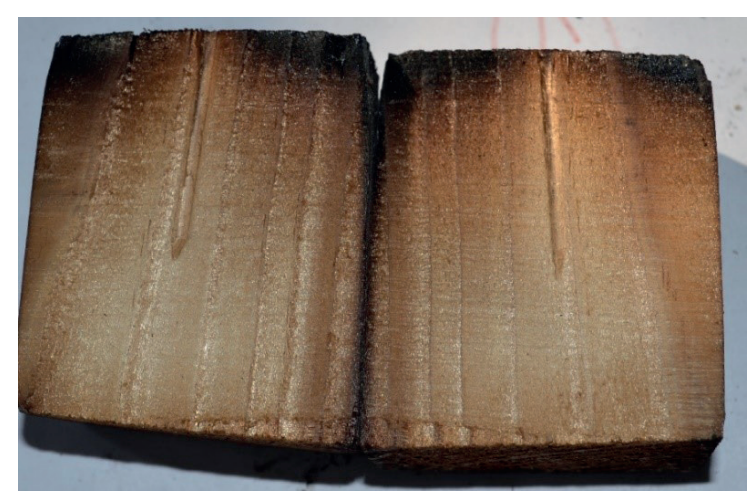

Fig. 10 Discolouration of the cut surface (edited by the authors)

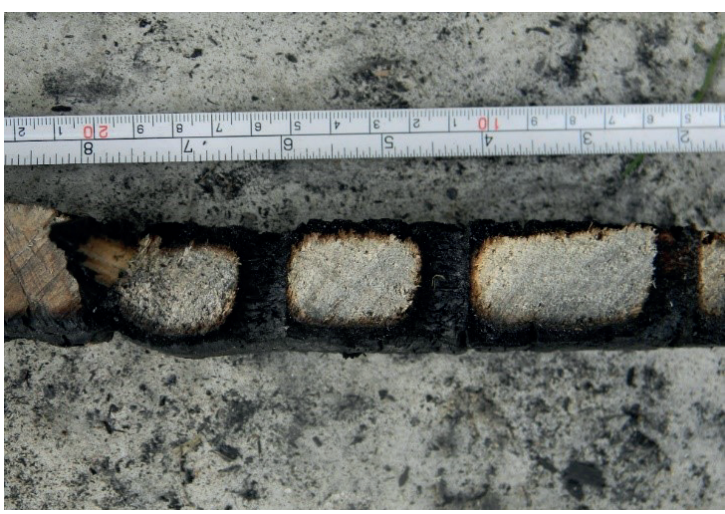

Fig. 11 Discolouration at the screws (made by the Authors)

\section{Conclusions}

The aim of our research was to analyze and investigate the effect of wood defects and fasteners on fire resistance. During the tests, the effect of wood defects and metal fasteners on fire resistance was investigated. Table 2 summarizes our experiment series.

Table 2 Fire resistance test of wood defects (made by the authors)

\begin{tabular}{|c|c|c|c|c|c|}
\hline Type of wood deffects & $\begin{array}{c}\text { Size of } \\
\text { speciemen }\end{array}$ & Heat load & Heat effect & $\begin{array}{l}\text { Treatment after } \\
\text { combisition }\end{array}$ & Change \\
\hline Knot- $1^{\text {st }}$ series & $7 \times 7 \times 7 \mathrm{~cm}$ & electric furnace & $490^{\circ} \mathrm{C}$ self ignition & $\begin{array}{l}\text { after } 2-3 \text { min of } \\
\text { burning treating it in } \\
\text { water }\end{array}$ & $\begin{array}{l}\text { small carbonization different burn } \\
\text { depth depending on grainline }\end{array}$ \\
\hline Knot- $2^{\text {st }}$ series & & electric furnace & $\begin{array}{l}300^{\circ} \mathrm{C} \max \\
\text { temperature, glowing } \\
\text { not self ignition }\end{array}$ & $\begin{array}{l}30 \text { min heat load after } \\
\text { a difference of } 300{ }^{\circ} \mathrm{C}\end{array}$ & $\begin{array}{c}\text { minimal changes evaporating } \\
\text { moisture, easier to cut, minimal } \\
\text { carb. layer }\end{array}$ \\
\hline Knot- $2^{\text {st }}$ series & & open air flame & & & $\begin{array}{l}\text { from depth, faster burn near the } \\
\text { knot }\end{array}$ \\
\hline Insecticide effect & & & & & the insect route has not brunt \\
\hline Crack effect 1 & $3 \times 3 \times 18 \mathrm{~cm}$ & electric furnace & & & $\begin{array}{c}\text { increasing of the crack thickness, } \\
\text { large deformation }\end{array}$ \\
\hline Crack effect 2 & $\begin{array}{c}5 \times 15 \mathrm{~cm} \\
\text { plank pieces }\end{array}$ & open air flame & open air flame & $\begin{array}{l}\text { from } 6 \text { min } 30 \mathrm{sec} \text { to } \\
10 \mathrm{~min} \text { heat load }\end{array}$ & thicker carb., visible cracks \\
\hline Metal fasteners effect & & & & & $\begin{array}{l}\text { minimal carb. around the metal } \\
\text { angle, major carb. at larger screws }\end{array}$ \\
\hline
\end{tabular}


The conclusions drawn from the series of tests are the followings:

- The direction of the knots influences the level of burn.

- At the temperature of $300{ }^{\circ} \mathrm{C}$ in glowing state the effect of the knots cannot be investigated.

- In the specimens exposed to open flame, a shrinkage was observed at the knots, so separating it from the rest of the wood.

- Insect pests have no effect on the burning rate of wood.

- Existing cracks will continue to open.

Based on the experimental results, it can be concluded that the investigation of wood defects requires further investigation. It is advisable to investigate wood defects in a complex manner, considering formal and structural defects and their external influences. For accurate

\section{References}

[1] Németh, K. "A faanyag degradációja" (Degradation of Wood), Mezőgazdasági Szaktudás Kiadó, Budapest, Hungary, 1998. (in Hungarian)

[2] Schäfer, E. L. "Charring rate of selected wood-transerve to grain", Research Paper, U. S. Forest Service, Forest Products Laboratory, Madison, WI, USA, 1967.

[3] NationalFireProtectionAssociation"Atüzmintákelemzése"(Analysis of fire patterns), Promatt Elektronika, pp. 1-20. 2019. [online] Available at: http://www.electromuller.hu/letoltesek/NFPA921_4.pdf [Accessed: 02 May 2019] (in Hungarian)

[4] Frangi, A., Fontana, M. "Charring rates and temperature profiles of wood sections", Fire and Materials: An International Journal, 27(2), pp. 91-102, 2003.

https://doi.org/10.1002/fam.819

[5] European Committee for Standardization "EN 1995-1-2 Eurocode 5 Design of Timber Structures. General. Structural Fire Design", CEN, Brussels, Belgium, 2004. evaluation, it is necessary to develop a heat load mode that provides similar conditions for all series, so to provide a suitable burn depth.

\section{Acknowledgement}

This research was also supported by the János Bolyai Research Scholarship of the Hungarian Academy of Sciences. "Supported by the ÚNKP-19-4 New National Excellence Program of the Ministry for Innovation and Technology." The research reported in this paper was supported by the Higher Education Excellence Program of the Ministry of Human Capacities in the frame of the Water sciences \& Disaster Prevention research area of the Budapest University of Technology and Economics (BME FIKP-VÍZ).

[6] Frangi, A., Fontana, M. "Fire Performance Of Timber Structures Under Natural Fire Conditions", Fire Safety Science, 8, pp. 279-290, 2005.

https://doi.org/10.3801/IAFSS.FSS.8-279

[7] Erchinger, C., Frangi, A., Fontana, M. "Fire design of steel-to-timber dowelled connections", Engineering Structures, 32(2), pp. 580-589, 2010 .

https://doi.org/10.1016/j.engstruct.2009.11.004

[8] Bednarek, Z., Griškevičius, M., Šaučiuvėnas, G. "Tensile, Compressive and Flexural Strength Reduction of Timber in Fire", Statybinès konstrukcijos ir technologijos, 1(3), pp. 148-156, 2009. https://doi.org/10.3846/skt.2009.18

[9] Jong, F., Clancy, P. "Compression properties of wood as functions of moisture, stress and temperature", Fire and Materials: An International Journal, 28(2-4), pp. 209-225, 2004. https://doi.org/10.1002/fam.859

[10] Kordina, K., Meyer-Ottens, C., Scheer, C. "Holz-brandschutz-Handbuch" (Handbook of wood fire safety), Beuth Verlag, Berlin, Germany, 1994. 